See discussions, stats, and author profiles for this publication at: https://www.researchgate.net/publication/319873334

\title{
Language awareness in action: Primary school students' language practices while performing a multilingual task
}

Chapter · January 2017

DOI: 10.1515/9781501501326-008

CITATIONS

0

2 authors:

(a)

Koen Van Gorp

Michigan State University

38 PUBLICATIONS 139 CITATIONS

SEE PROFILE
READS

618

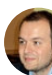

Steven Verheyen

Erasmus University Rotterdam

57 PUBLICATIONS 482 CITATIONS

SEE PROFILE

Some of the authors of this publication are also working on these related projects:

Evaluation research into the Home Language in Education (HLiE) project, Ghent, Flanders (2008-2012) View project

Project Probabilistic accounts of vagueness View project 


\title{
Koen Van Gorp and Steven Verheyen
}

\section{Language awareness in action: Primary school students' language practices while performing a multilingual task}

\begin{abstract}
This chapter discusses the language awareness (LA) practices that arise among students and teachers while performing a multilingual task called Radio Tika in Flemish primary classrooms. Radio Tika is a task that promotes primary school students' full use of their linguistic repertoire. The task challenges the students to present the radio news for the fictitious Tikaland in as many languages or language varieties as possible. Students' language choices and practices while preparing their task performance give rise to reflections and discussions about languages and language use, create opportunities for students to position themselves as experts, but also confront them with their limitations. This chapter discusses the value of the wide range of spontaneous LA practices that emerged in several Flemish primary school classrooms that differed greatly with respect to linguistic/ethnic composition.
\end{abstract}

\section{Introduction}

Language awareness (LA) as an approach to language education in schools has travelled a long and winding road. Its history differs from country to country. Up to now, in Flanders, Belgium, LA has not really been incorporated in the curriculum of either primary or secondary schools. Whereas LA received more attention in the French speaking part of Belgium it was never fully introduced in Flanders, the Dutch speaking part of the country. Nevertheless, since around 2010, it has received some special attention from the Department of Education and from the educational networks in Flanders (see Chapters 1 and 2 in this volume). The increasing interest in LA was fuelled by the growing number of second language learners in the Flemish educational system and the need to address equity issues in education. Developing LA in all students through intentional and incidental LA activities was believed to help foster mutual understanding and respect toward other languages and their speakers.

In this chapter we first discuss the role, or rather, the lack of role home languages other than Dutch, the dominant language in the Flemish educational system, have in the education of students. We briefly explain the monolingual ideology pervading Flemish education and argue how translanguaging, paying attention to multilingualism and LA might help to develop a sensitivity to and awareness of the existence of a multitude of languages and associated underlying cultures and frames of reference in our world. Second, we describe a multilingual task that was used as a research task in three different studies over a period of five years to uncover teachers' and students' beliefs and practices regarding 
multilingualism. This task was proposed to seven primary school classrooms across Flanders and allowed us to collect information on the incidental, spontaneous LA "moments" that arose in the interactions among students and teachers while performing the task. We describe and discuss our findings in terms of the organic LA practices and reflections they brought about in students and teachers. Finally, we conclude this chapter by discussing the potential of translanguaging and LA in creating a space where students' voices are heard and where teachers and students discover the multilingual identities of each other.

\section{Educational language policy in Flanders, Belgium ${ }^{1}$}

Belgium is officially a multilingual country. As a federal state, it consists of three languagebased communities (Dutch, French, and German) and is divided in three territory-based regions: Flanders (the Dutch-speaking part), Wallonia (where French and German are the official languages) and the Brussels-capital (bilingual French-Dutch). In such a political and linguistic landscape, one would expect citizens to grow up bi- or multilingual and inhabitants to have a positive attitude towards multilingualism. However, language is a sensitive issue in Belgium. Relations between the Flemish and French communities are complicated due to historical reasons, causing Flemings to react, sometimes heavily, against the use of French both in the educational and public space in Flanders and Brussels (Willemyns 2003). The historical and politically anxious relation between the use of Dutch and French, as well as an intolerance within Flanders to cultural and linguistic diversity (e.g., Blommaert and Verschueren 1998), has engendered problematic relationships with immigration, creating a kind of spill-over effect that causes negative feelings and reactions against almost all ethnic minority languages (Jaspers 2004).

The problematic relation with multilingualism and the monolingual attitude of the Flemings, especially in the educational system, has been evidenced time after time (Jaspers 2004, 2011; Pulinx, Van Avermaet, and Ağirdag 2015; Van den Branden and Verhelst 2008) and is enacted in a dominant Dutch-only language policy (e.g., Ağirdag, Jordens, and Van Houtte 2014; Jaspers 2011; Van Gorp 2012) reflecting the territorial monolingualism of the Flemish community (Blommaert 2011). From preschool through secondary school, schools promote language behaviour like "When at school, speak Standard Dutch" (Jaspers 2011: 1267). The Dutch-only or speak-Dutch rule most schools and educators adhere to is based on the assumption that the rate and quality of (second) language acquisition depends on maximum exposure to the target language: more and earlier exposure to the target language is believed to lead to better target language development (Strobbe et al. 2017). Common sense ideas of competition between languages, time-on-task (or frequency of input) and possible negative transfer between languages seem to underpin the perception of educators 
that exposing children to Dutch as much as possible is of the utmost importance and in their best interest (Ağirdag 2009; Strobbe 2016).

This "radical monolingualism" (Jaspers 2011: 1267) is reflected in the Onderwijstaalwet ['Education Language Law'] of 1963 that prescribes that the language of instruction must match the language of the official language communities in which schools are located, that is, Standard Dutch for the Flemish community. Until recently, Content and Language Integrated Learning (CLIL) where at least part of the curriculum is taught through another language (e.g., English or French) could only be organized in secondary education. A recent policy document cautiously provides an opening for promoting other languages than Dutch in Flemish primary education. From school year 2017-2018 onward, students may receive language initiation in French, English, or German from grade 1 and take English and German as a school subject next to French from grade 3, but only if they "have already acquired a sound basis of Standard Dutch" (Crevits 2016: 7). The importance of Standard Dutch on the policy level remains uncontested (Van Gorp 2012) and the opening that the Flemish Department of Education creates for promoting other languages than Dutch is explicitly restricted to the languages of neighbouring countries and languages high up on the hierarchical language ladder (Cornips 2012). ${ }^{2}$

If the educational policy puts so much emphasis on Standard Dutch, it should not come as a surprise that most primary school teachers believe firmly in the value of a Dutchonly school language policy (Strobbe 2016). Important to note is that from a legal point of view, one could argue that the Dutch-only rule is the result of a misinterpretation of the Education language law. The website of the Flemish government points this out in a very clear manner: "To be clear: the language law holds for the schools and not for the students or parents" (Steunpunt Taalwetwijzer 1 June 2013). So, the Education Language Law does not specify that students and parents must speak Dutch on school property. This provides schools with a lot of leeway in how to approach languages other than Dutch. This is especially important since the exclusion of home languages might have negative effects on the well-being and the academic performance of students (Gándara and Hopkins 2010; Young 2014). Furthermore, Cummins advocates for positive attitudes towards, or even support of the home language for reasons of identity investment:

To reject a child's language in the school is to reject the child. When the message, implicit or explicit, communicated to children in the school is "Leave your language and culture at the school-house door", children also leave a central part of who they are - their identities - at the school-house door. When they feel this rejection, they are much less likely to participate actively and confidently in classroom instruction. (Cummins 2001: 19) 
Dealing with linguistic diversity in the Flemish classroom apparently poses an educational challenge (it is the same in other European contexts, see other chapters in this volume: Chapters 1 and 2 for Belgium; Chapters 3, 6 and 8 for France; Chapter 5 for Ireland; Chapter 4 for Spain). A lot is at stake: providing optimal language education for all children, and especially immigrant and minoritized children. Banning the home languages of these children under the pretence of creating a powerful language learning environment for these students to learn the language of schooling or Standard Dutch, might not be the best way to address this educational challenge. On the contrary, it might send a negative message to children and parents about their linguistic identity, and in fact, their identity as immigrants or citizens of the country they were often born in.

To mitigate the impact of a Dutch-only policy and to promote a more favourable attitude toward all kinds of multilingualism, an empowerment-based and multi-strand strategy to multilingualism seems to be needed. Such an approach combines stimulating the language of schooling in a functional, task-based approach with allowing or even promoting the home languages for identity development, socio-emotional and functional use, that is, as didactic capital, as a cognitive tool to mediate content learning or facilitate second language development (Berben, Van den Branden, and Van Gorp 2007; Van Gorp 2012; Van Gorp and Moons 2014; Van Gorp 2008; Van den Branden and Verhelst 2008).

Sierens and Van Avermaet $(2010,2014)$ coined the term "functional multilingual learning" (FML) for this multi-strand approach to learning. FML does not focus on bilingual education but takes into account that most classrooms are linguistically heterogeneous, and have students that speak a multitude of languages at home. It presents itself as an approach that any teacher can employ to use the linguistic diversity in her or his classroom as didactic capital. FML offers multilingual students "opportunities for using their first language as a scaffold for learning language and subject-specific content" (Rosiers et al. 2016: 268). As Jordens (2016: 132) points out: "A whole range of multilingual activities meets this description". From a simple "Good morning" in the mother tongue of a pupil or parent, or singing songs in other languages, to inviting parents to participate in the class like in the Didenheim project in Alsace (Hélot and Young 2003; see Chapter 3 in this volume), creating dual-language books (Chow and Cummins 2003; see Chapter 5 in this volume), using tasks to create multilingual output (Berben, Van den Branden, and Van Gorp 2007; see below) or even promoting a multilingual digital learning environment for social studies and science lessons like e-Validiv (Van Laere, Aesaert, and van Braak 2014).

In this operationalization FML links up with the concept of translanguaging not just as a communicative practice but specifically as an educational practice. García (2009) provides a clear definition of translanguaging as a communicative practice: 
the act performed by bilinguals of accessing different linguistic features or various models of what are described as autonomous languages, in order to maximize communicative potential. It is an approach to bilingualism that is centered, not on languages as has often been the case, but on the practices of bilinguals that are readily observable in order to make sense of their multilingual world. (García 2009: 140, authors' emphasis)

By embedding these communicative practices in an educational context, García and colleagues are developing translanguaging as a pedagogy that focuses on the "use of the learner's full language repertoire in teaching and learning" (García, Seltzer, and Witt in press). Or as García and Li Wei (2014: 89) state: "For learners, translanguaging is a way to become more knowledgeable as language practices are expanded, for teachers, a pedagogy to educate children holistically". Doing so, minority students' learning can be improved and their identity as successful students can be boosted.

These descriptions leave a lot of room for interpretation and do not always make clear what the exact role of translanguaging is, but there is a vast literature on how the home languages of young learners can support content-based learning and second language learning (e.g., Benjamin 1996; Eldridge 1996; Jordens, Van den Branden, and Van Gorp 2016; Moodley 2007; Møller, Jørgensen, and Holmen 2012; Reyes 2004; Swain and Lapkin 2000). Furthermore, allowing translanguaging in the classroom goes hand in hand with creating and stimulating opportunities to develop students' language awareness (Ramaut et al. 2013).

LA has proven to be a potentially valuable empowering approach (see Chapter 1 in this volume). Based on the existing empirical evidence Frijns et al. (this volume) provide the following definition:

LA aims at the development of sensitivity to and awareness of the existence of a multitude of languages and associated underlying cultures and frames of reference in our world. The potential of LA is situated in [...] (1) the affective domain, by creating an attitude of openness and sensitivity towards linguistic diversity; (2) the cognitive domain, by improving knowledge about and insights into language and metalinguistic skills and (3) the social domain, by improving the engagement and well-being of students, especially ethnic minority children, if their linguistic identity is welcomed unconditionally at school. (Chapter 2: Page to be added) 
Frijns et al. argue for an emergent, bottom-up and open perspective on LA. Rather than teaching LA through structured activities as part of a curriculum, the key to developing sensitivity to and awareness of the existence of a multitude of languages as well as embedded knowledge about these languages, is allowing spontaneous LA moments to arise out of regular learning tasks and daily classroom activities. Creating opportunities for the students' multitude of languages to be used in the classroom and creating a translanguaging space could promote these spontaneous occurrences of LA.

In the present study, we investigate how students and teachers respond to the introduction of a multilingual task in primary school classrooms and whether such a task gives rise to spontaneous LA practices.

\section{The multilingual task: Radio Tika}

\subsection{The task}

The task Radio Tika was developed by professional task-based syllabus designers at the Centre for Language and Education of the KU Leuven (see Berben, Van Gorp, and Van den Branden, 2007, and Van Gorp 2008 for details). The task description invites the students to create a multilingual radio news broadcast for the radio station Tika. This is the official radio station of the fictitious multilingual country Tikaland. The task was written for the 5th and 6th grade of Flemish primary schools. In Flanders, children reach the 5th grade by the age of 11 and the 6th grade by the age of 12 . Official attainment targets issued by the Flemish government mention that with regard to speaking skills, children should, for instance, be able to deliver oral reports to other students and to their teacher by the end of primary education (Departement Onderwijs 1998).

The students work in small groups, practice their cooperative skills and use their full language repertoire to create a multilingual radio news bulletin and listen to other groups' news bulletins. Each group provides the audience of their news broadcast with a listening task by formulating three listening comprehension questions in Dutch. These questions act as a comprehension check and a basis to discuss the experience of listening to languages that might be unfamiliar or unknown to students.

Radio Tika is a task that meets the criteria of task-based education (Van Gorp and Bogaert 2006). Constructing a news bulletin involves a lot of relevant (academic) language about the world of radio broadcasts (domestic news, foreign news, sports, a weather forecast) that are relatively abstract and unknown to the children. Creating a news bulletin is a motivating activity; one that challenges the students but also allows them to construct messages at their own level of proficiency. The peer interaction and interaction with the teacher that the task elicits, and especially the limited time allotted to the news bulletin (e.g., 
three minutes), will "push" the output of the children to a higher level of proficiency. The syllabus designers had one additional goal in mind when developing this task: promoting multilingualism. The task instructions invite the teacher to instruct the students to present the different topics in their news bulletin in different languages. In order to do so, the teacher is invited to compose multilingual groups. Consequently, the task allows for the use of multiple languages and for translanguaging practices to occur in the classroom. It engages students “in complex discursive practices in order to 'make sense' of, and communicate in, multilingual classrooms" (García and Sylvan 2011: 389). In determining their language choice and during their translanguaging practices spontaneous moments of LA are likely to emerge, seeing languages are the focus of the groups' discursive practices.

At the end of the activity, after all the news bulletins have been presented, the teacher is invited to discuss the use of the different languages with her/his students: how did the students experience making their own language choices? Did they discuss in group who was going to speak which language? Were they able to understand all the information presented? Would they like to have multilingual broadcasts in Belgium? Giving the students' home languages a central role in the educational activity, and bringing multilingualism out into the open (in an otherwise monolingual classroom) during the performance of a motivating task, may be an efficient way to promote the value of each of these languages, to foster respect for multilingualism, and to boost the students' pride of being able to speak more languages than Dutch only.

\subsection{Radio Tika studies: Context and participants}

This chapter brings together results from three recent studies in grades 5 and 6 of primary school (student ages 10-12). In each study, we introduced Radio Tika to disclose teachers' beliefs about multilingualism and home language use and to observe both teachers' and students' actual classroom behaviour and language practices. The classrooms in the different studies differed considerably with respect to the percentage of multilingual students and the socio-economic status of their parents, reflecting the variety of Flemish primary school classrooms. Apart from the European school in Pauwels (2013), all schools were Dutch-medium schools with an explicit (e.g., in a school document, on the school website) or an implicit (e.g., agreed on by the school staff but not officially documented) Dutch-only language policy. All teachers were aware of the school language policy and acknowledged the importance of speaking Dutch at school. Table 3.1 provides a schematic overview of the classrooms involved in the different studies. 
Table 3.1: Overview of contexts and participants

\begin{tabular}{ccccccc}
\hline Study & City & Multilingual & SES & NClass & $\begin{array}{c}\text { Nobserved } \\
\text { per group }\end{array}$ & Excerpts \\
\hline Van & & & & & & \\
Bruyssel & Brussels & $90 \%$ & average to high & 18 & $4+4$ & $5,14 \mathrm{a}-\mathrm{d}$ \\
& Ronse & $75 \%$ & low & 26 & $4+4+4$ & 6 \\
& Ghent & $50 \%$ & low to average & 18 & 5 & 10 \\
Pauwels & Molenbeek & $90 \%$ & average & 16 & $4+4$ & 7 \\
& Molenbeek & $100 \%$ & high & 13 & $4+4$ & 9 \\
Heylen & Turnhout & $30 \%$ & low to average & 13 & $4+4+4$ & $1,2,3,11,12$ \\
& Dilsen & $30 \%$ & average & 21 & $4+4+5$ & $4,8,13$ \\
\hline
\end{tabular}

Van Bruyssel (2011) introduced the Radio Tika task in three classrooms in different primary schools. The first was a school in Brussels with $90 \%$ of the students having French as a home language and mostly highly educated parents. The second one was a school in the city of Ronse, near Brussels, with $75 \%$ multilingual students (one third being of Moroccan origin, most students from parents with a low socio-economic background). The third school, in the city of Ghent, had about 50\% multilingual students - especially from Turkish origin, almost all from parents with a low socio-economic background.

Pauwels (2013) conducted a second study in two classrooms in different schools in Molenbeek, a municipality in Brussels-Capital Region. The first classroom was comprised of 90\% multilingual students who mainly had French as a home language and middle class parents. The second classroom was part of a European school. All of the students were multilingual and had highly educated parents. ${ }^{3}$

Finally, Heylen (2015) conducted a study in a school in Turnhout (a mid-sized town in the province of Antwerp, near the Dutch border) and a school in Dilsen (a suburb of a midsized town in the province of Limburg). Heylen (2015) focused on how the multilingual task would play out in classrooms with only $30 \%$ multilingual students. About $50 \%$ of the students in the classroom in Turnhout had parents with a lower socio-economic background. The students in the classroom in Dilsen represented a socio-economic mix, mirroring the different neighbourhoods (some with families of especially high and some of especially low socioeconomic background) surrounding the school.

\subsection{Method}

All three studies followed a similar data collection and data analysis approach. In this paragraph, we will briefly outline this approach. Table 3.2 provides an overview of the data collection in each study. In total seven classrooms in seven different schools were involved. 
Table 3.2: Design of the three Radio Tika studies

\begin{tabular}{|c|c|c|c|c|c|c|}
\hline \multirow[t]{2}{*}{ Study } & \multicolumn{3}{|c|}{ Interviews } & \multirow{2}{*}{$\begin{array}{c}\text { Questionnaire } \\
\text { Students }\end{array}$} & \multicolumn{2}{|c|}{ Observations } \\
\hline & Principal & Teachers & Students & & $\begin{array}{l}\text { Regular } \\
\text { Classroom }\end{array}$ & $\begin{array}{c}\text { Radio } \\
\text { Tika }\end{array}$ \\
\hline Van Bruyssel & & Pre \& Post & & & $x$ & $x$ \\
\hline Pauwels & & Pre \& Post & & Pre & $x$ & $x$ \\
\hline Heylen & Pre & Pre \& Post & Post & Pre & $x$ & $x$ \\
\hline
\end{tabular}

Note . Pre = before the Radio Tika task; Post $=$ after the Radio Tika task

In each study, the teacher of each classroom was interviewed before and after the task. The interviews in the three studies followed the same structure. In the first semi-structured interview the teachers were asked to describe their students and their own teaching history. Next, they were asked about their views on multilingualism, their language teaching approach, and the language policy of the school. In the second semi-structured interview the teachers were asked about their experience with the task and whether the teacher would perform the same task or similar tasks in the future (e.g., next school year). The teachers were invited to reflect on their own and their students' experiences and on the classroom discussion following the task (if there was any). Although they were not explicitly asked about their views on multilingualism in the second interview, the teachers spontaneously referred to it during their reflection. Heylen (2015) also interviewed the students after the task. She focused on the students' experiences, their language choice behaviour, and their views on multilingualism in general. Furthermore, Heylen (2015) interviewed the school principals about their school population, the neighbourhood, and the school language policy.

All classrooms were observed by the researcher before the Radio Tika task (as a baseline) and during Radio Tika. The researcher wrote field notes focusing on language behaviour of the students and teacher comments on language use and multilingualism. During the Radio Tika tasks at least two groups of four to five students were either audio- or videotaped. Both audio and video recordings were able to capture almost all of the language production of the group interactions. A video camera often allowed for a more precise identification of the speakers (about 16 students per study), however, the angle of the video camera did not allow to identify all speakers all of the time.

Pauwels (2013) and Heylen (2015) used questionnaires to collect background information on the students (home languages, perceived language proficiency, educational level of parents, etc.) and used the information on home languages and perceived language 
proficiency level to form heterogeneous groups for the Radio Tika task. Van Bruyssel (2011) left it to the teacher to form heterogeneous groups.

The interviews were transcribed and analysed thematically following a similar set of $a$ priori determined topics (e.g., the interview topics listed above). The primary researcher listened to or viewed the recordings of the groups performing the task. Language and language choice related episodes were identified and transcribed. These episodes were discussed with the supervisors of the studies (Van den Branden for the first study, Van Gorp and Verheyen for the other two studies) following the procedure of critical incident analyses (Kroon and Sturm 1996) to avoid subjective interpretations of the incident, striving towards consensus and intersubjectivity. Due to constraints of time and money, the incidents were only transcribed in the languages the primary researcher was proficient in.

In this chapter, we discuss the critical incidents that were identified as LA practices by the primary researchers and/or by the two authors of this chapter (in an independent reanalysis of the data). In order to be identified or reconfirmed as LA practices, the critical incidents in the studies of Van Bruyssel (2011), Pauwels (2013), and Heylen (2015) had to show evidence of students' sensitivity to and conscious awareness of language and its role in their life, or the existence of a multiplicity of languages, and their underlying cultures and frames of reference. This working definition was based on Donmall (1985: 7) and Sierens et al. (see Chapter 1: page numbers to be added). Only the incidents on which at least two of the three researchers agreed upon were used for this chapter. In an overview of the three studies, we present a representative sample of the often spontaneous language reflections made by students and teachers in the groups that were recorded and in the class discussions that followed the group performances. Before we do so, we present an overview of a number of other findings from the Radio Tika studies as a background for the present findings.

\subsection{General findings from the Radio Tika studies}

All Radio Tika studies observed tensions between the official school language policy, which was an explicit or implicit Dutch-only policy, and the language practices in the classrooms. Whether teachers supported the Dutch-only policy or not, language practices in all classrooms were more diverse than a Dutch-only policy would dictate. How overtly diverse these practices were was often related to the teachers' beliefs about the importance of learning Dutch (paramount over, for example, well-being or not), the role of the home language in learning Dutch (a hindrance or not) and multilingualism in general. The more positive the teachers' attitudes were toward being multilingual, the more multilingual practices were tolerated or even encouraged during the Radio Tika task. However, teachers who adhered to a deficit view and believed a Dutch-only policy was the only way to promote 
students' development of Dutch as a second language, responded in a more restrictive way toward the task and the multilingual practices Radio Tika elicited in their classroom.

Regardless of whether the teachers adopted a more restrictive versus a lenient or open approach to multilingualism, translanguaging practices were observed in all seven classrooms to a certain extent. For most students, translanguaging came natural. They used their whole language repertoire communicating with other students. In fact, Radio Tika enabled many of the students to act as a specialist or expert on their language. During the task performance students showed interest in the languages of other students and this filled a lot of students whose home language had never been an object of interest in the classroom with pride. Nevertheless, in each classroom there were some contested language choices and some students were unwilling to use their home language in front of the other students. The uniqueness and/or the status of their home language in the classroom, the compartmentalization of their home versus school language, a perceived limited L1 proficiency (e.g., in the formal register, for writing) and an awareness of not being able to live up to the language accuracy norm of the classroom, were some of the language-related issues that fed students' reluctance to use their home language during task performance (Heylen 2015; Pauwels 2013; Van Bruyssel 2011). Other factors were related to peer and teacher pressure or to personality traits. Finally, while preparing for and practicing the multilingual news bulletins many spontaneous LA moments emerged, underscoring the feelings of pride and expertise of the students.

\section{Language awareness moments during a multilingual task}

In this section, we organize the critical incidents that were identified as LA practices in the studies of Van Bruyssel (2011), Pauwels (2013), and Heylen (2015) into seven themes. Each theme is illustrated with several excerpts from the student-student and student-teacher interactions. ${ }^{4}$ Due to space limitations, we only provide the English translations of the Dutch utterances. ${ }^{5}$ Where participants used a language other than Dutch that the primary researcher could comprehend, the utterance is provided in that language. For each of the excerpts, the reference to the original Dutch utterance and its context (see Table 3.1) is provided.

\subsection{Being interested in languages}

Engaging in a multilingual task like Radio Tika offers students opportunities to get exposed to and show interest in other languages. It enables them to express how they feel toward their and other students' languages and to explore what they already know or think they know. An advantage is that these languages are not introduced or determined by the teacher but by 
fellow students, which makes the journey even more unexpected as the following four excerpts illustrate.

\section{Excerpt 1}

Joris: What does that say? Hoy?

Isabel: Hoy.

Joris: Hoy it's ten to thirteen degrees Celsius.

Isabel: But I don't know anything else.

Joris: I understand what "hoy" means. Of course, it's Spanish!

Frederik: Really? Is "hoy” Spanish?

Joris: It seems so, hu. Is Sunday "hoy"? Sunday is "hoy".

Isabel: That isn't true. It's today.

Joris: Ah it's today. Hoy!

(Heylen 2015: 44 - Turnhout)

\section{Excerpt 2}

Isabel: What day is today?

Amélie: Today? Thursday, May 21.

Isabel: I just need to know Thursday. Lunes, martes, miércoles... Jueves!

Amélie: I find that language beautiful.

(Heylen 2015: 44 - Turnhout)

\section{Excerpt 3}

Teun: Do you know English?

Rachna: We speak English at home. Well, often.

Teun: Really? You do?

Rachna: Yes!

$(\ldots)$

Teun: Say something in English. 


\section{$(\ldots)$}

Rachna: Yes, I am ready too.

Teun: Say something, because I want to hear, how English sounds.

(Heylen 2015: 48-51 - Turnhout)

\section{Excerpt 4}

Leyla: I want to speak English. But Turkish is a beautiful and special language.

Fleur: I want to hear Turkish.

Leyla: Hear Turkish?

Fleur; Yes.

Leyla: Why?

Fleur: I never heard it.

Leyla: I don't want to speak Turkish. I want to speak English.

Lucas: Yes, do that.

(Heylen 2015: 61 - Dilsen)

Excerpt 1 illustrates how opening up a multilingual space in the classroom allows Frederik to find out that certain words like "hoy" (which sounds very similar to the Dutch hoi ['hi']) are part of a particular language and what they actually mean. It also allows students to express their feelings toward foreign languages, like Amélie in Excerpt 2 who thinks Spanish is a beautiful language. By preparing the radio broadcast students discover, sometimes unexpectedly, that their peers speak other languages and show an interest in these languages, especially how they sound, as evidenced in the classrooms in Turnhout and Dilsen (Excerpts 3 and 4). Teun did not know Rachna spoke English at home (Excerpt 3). He is surprised to learn this and is now really interested in hearing Rachna speak English. He asks her several times to do so. In the classroom in Dilsen (Excerpt 4), Leyla is unsure which language to choose: English or Turkish. She would prefer to speak English, but Turkish is a beautiful and special language. Fleur has never heard anyone speak Turkish. She is curious about Turkish and, therefore, pushes Leyla to speak Turkish. Leyla, however, wants to stick to English and is supported in her language choice by Lucas, another group member.

\subsection{Comparing languages: Emergent awareness}


Being involved with several languages during group work provides ample opportunities for students to register what the languages sound like, what words are being used, and other aspects of languages that students might find remarkable or special. This leads quite often to short moments of LA where students start comparing languages and language use. Excerpts 5 and 6 illustrate this.

\section{Excerpt 5}

Marco: But no. Uh, no, I can, (Points to work sheet.) this does not have to be written in Finnish.

Thierry: But it's funny. Really, with all those dots and accents.

Marco: There are not many accents in Finnish but

Thierry: But uh no, write in Dutch. (Writes down.) So! Foreign news bulletin: Japan. (Van Bruyssel 2011: 36 - Brussels)

In Excerpt 5 Marco is working on his news bulletin in Finnish. He is preparing his text; taking notes in Finnish and Dutch. Thierry asks Marco to write what he is going to talk about in Finnish. Marco points out that they can write their text in Dutch. But just seeing Marco's notes allows Thierry to notice that Finnish's spelling is quite distinct from Dutch and seems to have more "dots and accents". Thierry's remark provides Marco with an opportunity to display his knowledge about the language by pointing out to Thierry that in fact there are not that many accents in Finnish.

Excerpt 6 shows how different LA moments pop up during the preparation of the different news bulletins in the classroom in Ronse. At first, Miguel is not prepared to create a news bulletin in Spanish, his home language. He feels insecure. He is not sure he wants to present in Spanish in front of the class. Group members Albane and Olaf show a real interest in foreign languages and insist on Miguel using his home language for this assignment. They urge Miguel several times to say something in Spanish. At some point Miguel becomes so frustrated and angry that he leaves the group and starts working individually on his assignment. Working individually on his text, Miguel nevertheless chooses to write in Spanish overcoming his anxiety to use his home language in the classroom. Excerpt 6 starts when Miguel returns to the group with a weather forecast written in Spanish, lays it on the table and directs Albane's attention to his work.

\section{Excerpt 6}


Miguel: Albane. (Puts his work sheet on the table. Miguel has written down his weather report in Spanish.)

Albane: Ah, what is that? (Takes the sheet.) Ah.

Olaf: (Starts to read it, in a muted voice): Aora el tempo en tikaland.

On the sheet it says: "Aora el tiempo en tikaland. Mañana va acer mucha calor con $25^{\circ} \mathrm{C}$ grados. I el sabado va acer moucha calor mas ce ahier con mas de $32^{\circ} \mathrm{C}$ grados en toda tikaland. Esta era el tiempo para hoi."

Albane: Oh that's funny! What are you doing? The weather report?

Miguel: Yes.

Albane: Well uh.

João: Hey!! Mine is almost the same. Agora o tempo è.

On João's sheet it says: "Agora o tempo di sport. Ya pasó o campeonato di fútbol. Real Cardoso contra Santa Cruz. Hoi zero a dos, para Santa Cruz. Campeonato di Tikaland dos mil y once."

Olaf: (Also starts reading what Miguel has written, very slowly.) A-o-ra el tem-po en tika-ron.

Miguel: Tikaland.

Olaf: Tikaland. (Continues to read.) Ma, manij. Maanananana (Starts „singing".)

Miguel: Ahora el tiempo que

Olaf: va a acer mucha colora co color con vivitwintig gredos.

Miguel: Vivitwintig! (Laughs.)

Olaf: Vivitwintig grados

Miguel: Veinticinco.

Olaf: Huh? Veinticinco grados.

Miguel: Yes.

Olaf: Gredos.

Miguel: Grados.

Olaf: (Laughs.) Grados.

(Van Bruyssel 2011: 49 - Ronse) 
In Excerpt 6 we see a few spontaneous LA moments emerge. Olaf starts reading Miguel's weather forecast aloud. Without knowing any Spanish Albane is able to understand that Miguel has written about the weather. João who has written his sports bulletin in Portuguese is surprised to notice that what Olaf reads aloud sounds very much like Portuguese and is very comparable to how he started his news bulletin. Olaf continues reading Miguel's text slowly and starts a little play on the word mañana. Miguel models for Olaf what Spanish really sounds like. However, Olaf continues and when he pronounces '25' in a Dutch-like way (vivitwintig $\approx$ vijfentwintig), Miguel laughs and models the pronunciation of the word, asserting his role as specialist. Olaf repeats Miguel's pronunciation and continues with the next word 'degrees' (grados) and although he gets that word right he is unsure about the pronunciation and checks it with Miguel who confirms that Olaf pronounced it correctly.

The conversations between the students in these excerpts do not lead to in-depth LA considerations, but they are evidence of an emergent awareness that helps foster an interest and probably even respect for the home languages of fellow students and for language learning in general. Or as Ahmed told his teacher in the class discussion in Ghent following the news broadcast: "The coolest was Aïsha because I speak no Arabic, but I did understand a few words" (Van Bruyssel 2011: 72). Likewise, in the interviews Heylen performed with the students after the tasks, students pointed out the task allowed them to compare languages and discover aspects of those languages they were not aware of beforehand. Fleur told the researcher: "I knew that it went fast in Moroccan. In Turkish and Bosnian I did not know how it was, so I now was able to hear this." (Heylen 2015: 70). And Sven pointed out: "I thought that Abdel talked like Izza, so Moroccan. But that was actually a whole other language. That sounded differently" (Heylen 2015: 70).

Not only do the students start to compare languages, the task to create a multilingual radio broadcast also draws the students' attention to comparable language use situations. As Thierry in a classroom in Brussels noticed: "It is better: first French, Dutch, and Finnish. For it is often like that uh uh at the airport." (Van Bruyssel 2011: 31). Linking the task behaviour to daily language use is something that also comes up in the class discussions following the broadcasts (see section 4.7).

\subsection{Comparing languages: Towards deeper understanding}

The following two excerpts show how these spontaneous LA moments can lead to more fundamental considerations and more detailed comparisons between languages, evidencing a deeper understanding of language-related issues by students.

\section{Excerpt 7}


Amine: I do Moroccan and you do Arabic. That's not the same.

Aïsha: It is. It's the same.

Amine: Is not.

Ines: Go ahead, speak Moroccan then. I speak Arabic. Speak, speak.

(Amine and Ines talk in Arabic. They compare words.)

Amine: Table is $x x x$ in Arabic and yyy in Moroccan.

(Amine and Ines go on to talk in Arabic.)

Ines: Ah, Moroccan, there are different kinds of Arabic?

Amine: There are differences.

(Amine and Ines repeat the Arabic words for table.)

Ines: But I don't want to speak Moroccan in front of the class.

(Amine and Ines continue to talk in Arabic.)

$[\ldots]$

Ines: So now Amine in Arabic.

Amine: Ok. (Anime reads the text he prepared out loud in Arabic.)

Ines: (Looks surprised and puts her hand in front of her mouth and looks around the classroom.) No, don't talk like that.

Amine: That's Arabic.

Ines: That is not Arabic, that is Moroccan.

(Ines is asked for help by another group so Amine continues speaking Moroccan.)

Amine: $X X X$ (Speaks Moroccan.). How do you say two teams? FC Tikaland versus FC Dollarland?

Ines: There's no name for that. So you are going to speak in Arabic? But no, don't speak this language. Speak normal! Speak Moroccan.

Aïsha: You don't speak the real one.

(Ines helps to complete Amine's story in Moroccan/Arabic.)

Ines: But speak the Arabic I speak.

Amine: Ok. $X X X$ (Continues to speak in Arabic.).

(Pauwels 2013: 32-33 - Molenbeek) 
Excerpt 7 reveals an interesting dynamic between two students from Moroccan descent: Ines and Amine. For the researcher, it was hard to determine in which ways the two varieties of Moroccan Arabic differed from one another. The parents of the students came from different regions in Morocco. Ines' parents came from Fez, while Amine's parents came from Tangier. Therefore, we can assume that Ines and Amine speak and are comparing different varieties of Moroccan Arabic. That is also the conclusion they reach comparing how they refer to a table and other concepts in their specific varieties. For Ines this seems to be a revelation. She comes to the conclusion that there are different kinds of Arabic. She seems to assume that she speaks "proper" standard Arabic and that Amine speaks Moroccan. This is confirmed when Amine reads his text aloud and Ines acts surprised and even a little shocked. Apparently, the Moroccan Amine is talking is a language variety that Ines would never use in public. Aïsha seems to confirm that Ines is talking "proper" Arabic whereas Amine is not. Whatever the reason, Ines wants Amine to use her variety of Arabic. In the end, Amine seems to accept that and seems to switch to Ines' variety of Arabic.

\section{Excerpt 8}

Teacher: Now first decide among each other: what are we going to tell and who is going to say what in which language?

Izza: But Miss, Abdel and I both know Moroccan. And I also know Berber, but I don't know Berber very well.

Teacher: Do you dare to try?

(Izza nods no.)

Teacher: No?

Izza: No.

Teacher: Could you do French then?

(Izza nods no.)

$[\ldots]$

Abdel: Berber, is it like that? I have never heard it.

Izza: They were the first Moroccans in Morocco. Did you know that? Morocco is split in two, the Berber side and the Moroccan side.

Abdel: Yes I know. And I speak Moroccan.

Izza: I speak Berber. Even though I don't know it. 
Abdel: Why don't you speak it here then?

Izza: But I don't know how! Dad is fluent ...

Tess: You say: I speak it, but I don't know it.

(Heylen 2015: 78 - Dilsen)

Excerpt 8 illustrates how the students struggle with their language choice. Both Abdel and Izza speak Moroccan but only one of them can use that language for the news bulletin seeing the teacher wants different languages to be used. Izza points out that she also speaks Berber but only minimally. When the teacher asks Izza whether she dares to use it, she says no. The teacher then looks for another solution; however, seeing Izza cannot speak French the issue remains unresolved. When the teacher leaves the group, Abdel and Izza keep on practicing in Moroccan although they both know they cannot use the same language. Izza says a couple of words in Berber and this catches Abdel's attention. He has never heard Berber before. Izza sees this as an opportunity to explain to Abdel some of the history of Berber. When Abdel insists that Izza should speak Berber, she declines reiterating that she cannot really speak Berber (see Excerpt 10).

\subsection{A growing awareness of one's competency and limitations in the mother tongue}

As Excerpt 8 already shows, being challenged to use their home language or a foreign language in the classroom confronts the students with what they can and cannot do in these languages. On the one hand, the students feel proud and confident in using their home languages. As Marco in the classroom in Brussels puts it: "Yes, I am gonna do that in Finnish. Yes, I can, uh, I can talk really good uh uh Finnish. I can even talk about the tsunami in Japan. In foreign news" (Van Bruyssel 2011: 31). However, some of the students are overconfident. In the course of the activity they become aware that they are not used to writing in their home language or that their vocabulary does not allow them to express all the concepts and ideas they need to talk about a certain news topic.

Some students are aware of their limitations from the start and they decide not to use their home language. For example, Yasmina in the class in Turnhout indicated on the survey that she was a proficient user of Moroccan. However, when confronted with the choice to use Moroccan for the assignment, she backs down and tells both the other group members and the teacher that she only knows a few words of Moroccan: "I can. A few words. I know these words. But I cannot put all the words in the right place" (Heylen 2015: 34). Leyla told the researcher that the task confronted her with the fact that using Turkish in certain contexts can be difficult: "I did not know Turkish could be so difficult sometimes. Yes I did not think it difficult, but it is so different. If I talk Turkish at home, I can say what I want. But writing a 
sentence now and then having to translate that sentence and write it down again, looking, thinking 'was this like this'. And then I think: this is quite different" (Heylen 2015: 68).

Some students struggle with using their home language in the classroom and try to find ways to accommodate their limited language proficiency. A nice example of a coping strategy was provided by Faris. When he wanted to write "Yasser has committed suicide", he is confronted with the fact that he does not know the word for suicide in Bosnian and says to his fellow students: "But ah, I do not know so much Bosnian. I am just going to say 'Yasser is dead'. Yes, can I write 'Yasser is dead'?" (Heylen 2015: 74). Other students feel that they want to switch language being confronted with the limitations in their language proficiency. Aaron in Excerpt 9 is such a student. Aaron's father was born in Congo, his mother is German. He speaks French at home. Next to Dutch and French, he has indicated that he speaks English and German. German is also his second language at the European school.

\section{Excerpt 9}

Aaron: Was sollen wir heute machen?

Antonio: You speak German.

Dalila: I speak French. All three of us speak French. Or you speak Italian. And the two of us French.

Antonio: Yes, that will work.

Vanessa: Yes, I am d'accord.

Aaron: Ok.

$[\ldots]$

Aaron: Wie sollen wir das machen?

Dalila: In which language do you want to do that? German or uh ... in your other language?

Aaron: Was? Weiss ich nicht. Ik kan nicht soviel Deutch.

Dalila: You said: I don’t speak German very well?

Aaron: I can't write it that well.

Dalila: But you don't have to write, you have to speak.

Aaron: Ah ok, then I'll do it in ... French. (Immediately starts very enthousiastically:) Salut tout le monde, ... (Then he laughs.)

Dalila: (Interrupts.) No, we do French. 


\section{$[\ldots]$}

Aaron: I have to speak German. Ich muss Deutch sprechen. Du Italienisch. Dalila, das, du hast nur ein klein bischen. Soo. (Shows how little text she has using his fingers.)

\section{$[\ldots]$}

Teacher: You can already practice it.

Aaron: Anderlecht lost against AC Milan. But they didn't have all their players. Four of their players were K.O.

Teacher: In German huh?

Aaron: Huh? Oops (Laughs.). Anderlecht hat heute verlornen. (He stops talking and begins writing down a translation. This doesn't go very well.) I do Dutch.

Dalila: In which language are you going to?

Aaron: Dutch.

Dalila: No, you can't. (Slightly angry.)

Aaron: English.

Dalila: But no, he does English. (Points to Antonio.)

Aaron: No, he does Italian.

Antonio: No, English.

Aaron: Then I do English as well.

Dalila: But no, do German.

Aaron: I don't want German. (Raises his voice a little but continues to "smile", albeit more of a grimace.)

Dalila: But do something else in German then, I don't know. You can think, it doesn't need to be real, it can be just like that ...

$[\cdots]$

Aaron: No, I can't do it in German. There are too many words I don't know.

Dalila: But just do something else than that. Something else than what you wrote down.

Aaron: Ok. (Not convinced.) Anderlecht hat heute verlornen, uhm ...

Dalila: Against? 
Aaron: $A C$ milan hat gewonnen.

Dalila: And they take home the cup.

Aaron: Sie rapportieren ... um ... und Sie haben ...

Dalila: They won the cup.

Aaron: Sie hatten die pokal gewonnen. There you go. (He speaks very monotonously and uninterested.)

Dalila: There you go. Here. (Hands over a piece of gum.) Bravo.

(Pauwels 2013: 65-68 - Molenbeek)

At the beginning of the assignment Aaron is very enthusiastic to use German. He starts speaking German and agrees to do the assignment in German. He takes his task very seriously and together with Dalila he provides leadership to the group. When he starts a conversation with Dalila on how to proceed, Aaron indicates that his German might not be good enough and he specifies that he cannot write German very well. Dalila emphasizes that he does not have to write German, but only has to speak it. At that point, Aaron seems to want to change his mind and would prefer speaking French rather than German. Dalila points out that this is no longer an option, seeing French has already been chosen. Aaron seems to set his concerns aside and appears very involved. He even jokingly sets the rule that each group member should only speak the language of the assignment during the preparation of the radio broadcast. He sets the example by starting to speak German. This seems to indicate that Aaron has no trouble speaking German in front of his peers. However, when the teacher listens in on the group and invites Aaron to practice his text, Aaron reads the sports bulletin that he has written in Dutch. The teacher asks him to do it in German. When the translation does not come as fluently as he would expect, Aaron feels the need to write down his bulletin in German. He immediately discovers that this is hard and decides to present his sports bulletin in Dutch. Dalila does not agree with this and reacts even a little bit angry. At that point Aaron is looking for another language to present his sports bulletin in and decides on English, a language that has already been chosen by Antonio. Dalila forces Aaron to stick with German, although he does not really want that anymore. In fact, Dalila kind of bribes Aaron in sticking to German by offering him a piece of gum. Aaron continues translating his text into German, to discover again that it is too hard for him to do. There are too many words he does not know in German. Dalila tries to support him by saying he does not have to translate exactly what he has written down in Dutch. He can improvise. She even provides him with some scaffolding. With Dalila's help Aaron succeeds in getting the message across, but he seems to have lost his enthusiasm. Moreover, when he finds out that he has to 
perform his sports bulletin in front of the whole class, he becomes scared and wants to give up. In the end, he will present his radio bulletin in Dutch.

This excerpt illustrates clearly how for some of the students their language choice is or can become contested. Aaron's language choice becomes problematic when he discovers that his writing skills in German are not good enough to perform the task. In addition, talking about a soccer match, there are too many words that he is not able to translate to German. When he wants to choose another language, the other students prevent him from doing so because all the languages that Aaron wants to use have already been chosen by other group members. Some external motivation (getting a piece of gum) keeps Aaron on track for a little longer, but having lost the confidence in his ability to perform the sports bulletin in German, the idea that he has to perform in front of the classroom is enough for Aaron to withdraw from the group completely and decide on his own to perform his sports bulletin in Dutch. There are a lot of mechanisms at play here, but from a LA perspective the discovery that one's initial self-assessment of what one can do with a language might not always match reality or that for several reasons choosing a language might not always be unproblematic, could give rise to powerful LA moments if they are picked up by the group and by the teacher. For Aaron this was not really the case. In the case of some other students, contested language choices helped the teacher discover that some of the students were ashamed to use their mother tongue in the classroom or in a public space. For example, Van Bruyssel (2011) observed how Amal did not want to speak Berber even though his peers and the teacher showed a real interest. For Amal it became a rather frustrating experience.

\section{Excerpt 10}

Amal: I'm a little bit ashamed of it.

Teacher: Ashamed? Amal, ashamed? There's nobody here who knows it. It's just a matter of letting people hear what it is. You don't have to be ashamed of that.

Amal: (Hides his face with a piece of paper.) No.

Teacher: Amal, nobody is ashamed in this class. You know that. There's nothing to be ashamed of, is there? Just say "Look, I know Berber". Whether it is Berber, or or Moroccan, or Arabic ... Me, I don't even know the difference. I would like to hear it. I would like to hear it. Just a couple of sentences.

Nils: You do Berber.

Amal: Uhm no no. I can't do it. (Nods no.)

Kevin: And you, which part are you going to?

Amal: Miss, I won't know certain words, what they are. 
Teacher: Yes then you can put in a Dutch word.

(Teacher leaves the group.)

Amal: Ah but no no. (Laughs.)

Jacky: But dude just speak Arabic then.

Kevin: Ah yes.

Amal: I don't know how. (Extends his hand to Jacky. Acts as if he wants to strike him.) I really don't.

Kevin: But no, hardly anyone does. Only that lady can understand you. (Kevin points to the researcher.)

Jacky: Ah yes.

Nils: But you'll Berber huh.

Amal: Nooo.

$[\ldots]$

Researcher: If you prefer, you use English huh.

Amal: I don't speak, I don't speak Berber in public.

Researcher: In?

Amal: In pu-blic. I don't speak it.

Researcher: Just at home?

Kevin: But speak Arabic then!

Amal: (Sighs, annoyed.) Dude, I am Berber. I don't, I don't know Arabic.

(Van Bruyssel 2011: 62-63, 70 - Ghent)

Although the teacher encourages and tries to support Amal, he is too ashamed to speak Berber in the classroom. He indicates that he would not know all the words he needs to present his news bulletin. The fact that the teacher allows for translanguaging cannot convince him. He keeps repeating, also to the researcher, that he is too ashamed to use Berber in a public space. When another student pushes him to switch to Arabic, he clearly states that he does not speak Arabic and later on, he reiterates that he is Berber and that he does not speak Arabic.

In a private conversation with the teacher, he later explains that the Berber identity is associated with a lower class of people in Morocco and that Berber is only spoken at home. 
Amal told the teacher that Berber is considered a language of thieves. Amal's example shows how children are aware of the discrimination toward certain languages and people, and how an activity such as Radio Tika can help teachers to get a better insight in students' home languages and how some of these languages function outside the school context.

\subsection{Bridging the home-school and languages divide}

Teachers can also be surprised by some of the students' stories and students' confidence in speaking their home language, as was the case with the teacher in Turnhout in Excerpt 11.

\section{Excerpt 11}

Isabel: I'm ready! I'm really ready.

Teacher: And that's going to work?

Isabel: Yeah.

Teacher: Yeah?

Isabel: I speak Spanish every day at home anyway.

Teacher: You speak Spanish every day at home?

Isabel: With my mother.

Teacher: And your father? Dutch?

Isabel: Dutch. No because my mother says: You have to speak Spanish with me because if you go to Peru then you have to know Spanish. And you should be able to talk to your family there and you also have to know Dutch for school.

(Heylen 2015: 43 - Turnhout)

The teacher is amazed by the fact that Isabel is able to speak Spanish in front of the class. He apparently did not know Isabel spoke Spanish with her mother. The task enables him to see a different Isabel than he is used to in the classroom. He told the researcher that he saw a more confident public speaker during Isabel's presentation of the news bulletin than during her other presentations in the classroom, and he noticed that she spoke in a louder voice in Spanish than she normally does in Dutch. Both to the teacher and the researcher Isabel said that it was great being able to speak Spanish in the classroom. It was "Really nice, because it made me feel more at home" (Heylen 2015: 43). In response, the teacher asked Isabel: "Do you want to speak Spanish more often in the classroom? If you just translate it afterwards, than that is okay. Because I do not understand it" (Heylen 2015: 46). This teacher discovered a side of his student that he was not aware of. Some teachers do 
not seem to know exactly what languages students speak at home or assume that they only speak their first language at home (Van Avermaet et al. 2016; Van Gorp and Moons 2014). This teacher went so far as to open up a translanguaging space for Isabel outside the Radio Tika task.

During the Radio Tika task we noticed that most teachers were willing to allow translanguaging. We already noticed in Excerpt 10 that the teacher encouraged Amal to speak Berber, and to use Dutch in case he did not know a specific word in Berber. We found the same attitude with most teachers participating in the Radio Tika task. In the class in Brussels, the teacher told a student presenting in Finnish that if he did not know how to say "And this concludes our news bulletin" in his home language, he could just say it in Dutch (Van Bruyssel 2011). In that sense the Radio Tika task also created LA moments for the teachers. They experienced and acknowledged that not all students have the necessary vocabulary to talk about certain topics in the home language and that accommodations need to be made. One possible accommodation is opening a space for students to make use of their whole language repertoire and allowing them to translanguage.

\subsection{Being a language expert}

Radio Tika enables students to feel pride in their language competencies by providing opportunities for students to position themselves as language experts or, at least, to be perceived by their peers as experts regarding their home language(s). The preceding excerpts already provided us with indications of how students are positioned as experts. For example, in Excerpt 5 Marco tells Thierry about the spelling of Finnish and in Excerpt 6 Miquel models to Olaf how Spanish is pronounced. In Excerpt 12 we see how Ode helps Max to write the past tense of the verb to tackle.

\section{Excerpt 12}

Max (to Ode): How do you write tackled in English? In the past tense.

Ode: Morning ... (Here Ode is still thinking about a question from Yasmina.)

Max: How do you write that?

Ode: What?

Max: How do you write tackled in English?

Ode: Tackled.

Max: In the past tense.

Ode: Ok, hand over. (Writes something down.) I think it's like that. 
(Heylen 2015: 37 - Turnhout)

Once Max discovers that Ode speaks English at home, he turns to her for help. Max does so throughout the preparation phase.

In Excerpt 13 we see how in the class in Dilsen, Teun helps Jill. For both Jill and Teun French is a foreign language. Teun is more proficient and resourceful in using French and provides Jill with the necessary scaffolds to write a weather forecast in French.

\section{Excerpt 13}

Jill: How do you say that again: what is the weather like tomorrow?

$[\ldots]$

Jill: What was "the weather" again?

Teun: The weather... Wasn't that "le temps"?

Jill: Good thing I grabbed my book.

$[\ldots]$

Jill: Do you say "how is the weather" or "what is the weather like tomorrow"? Ooh, I'm... (Sighs.)

\section{$[\ldots]$}

Jill: How do you say "tomorrow the weather will be good"? No no, bad.

Teun: Here that first sentence: here it's always very nice or very bad. And there you go, you already have a short sentence.

Jill: But I want to say that for tomorrow.

Teun: Then say "here" huh, "chez nous" and then "demain". Here tomorrow.

(Heylen 2015: 51 - Dilsen)

Also among students that share a home language, we see that more proficient users help and often encourage the less proficient users allowing the latter to shine and have their own moment of glory. For example, in the classroom in Molenbeek (see Excerpt 7), Ines is more fluent and proficient in Arabic than Amine is. She helps Amine in writing up his news bulletin and helps him out with vocabulary choices. Being able to get some help from another student enables students to decide on which language to choose and sometimes helps them to get through the assignment as evidenced by Jill in Excerpt 13 or Aaron in Excerpt 9. 


\subsection{Opening up the discussion}

We hope to have shown how the introduction of a multilingual task can create a lot of LA moments among the students themselves and the students and the teacher. The moment that has the most potential to lift these spontaneous LA practices to a higher level of reflection and group discussion would be the class discussion following the presentation of the Radio Tika broadcasts. Although the different researchers observed some interesting class discussions, most teachers did not engage in a real, lengthy class discussion, let alone effective reflective practice. Consequently, the potential of reflecting together with the students on multilingual practices remained largely untapped. In the classroom in Brussels Van Bruyssel (2011) observed one of the most elaborate class discussions. It is an example of how a class discussion can add value to the task.

After the group presentations, the teacher from the classroom in Brussels asks the students how they experienced the task. She does not comment much on the positive or negative experiences the students talk about, but has the students discuss among each other. She does, however, push students to think about being multilingual and the role they assign to the different languages in their lives. One of the topics that is being discussed is the role of dialects as in Excerpt 14a. The teacher starts from the observation that the task allowed students to use their full language repertoire, including dialects. She asks what the students think about dialects.

\section{Excerpt 14a}

Teacher: Ok, how do you actually feel about that dialect? Do you think that it is a language like Dutch or French at home or English? Yes Ann?

Ann: It's less beautiful.

Teacher: You think it's less beautiful. But, yes Emma?

$[\ldots]$

Marco: Uhm yes because there are uhm three languages plus the dialect, (hesitates for a moment) or isn't that a language?

Teacher: Yesss.

(Van Bruyssel 2011: 27 - Brussels)

Some of the students noticed the use of this "strange" Dutch during the group presentations. Consequently, the teacher opens up the discussion whether dialects are languages like French or English and lets the students discuss among each other. Nevertheless, she clearly voices her own opinion with a clear "Yes" that she throws in the 
discussion. Next the teacher links the multilingual situation in Tikaland with the situation in the classroom and in Belgium, as evidenced in Excerpt 14b.

\section{Excerpt 14b}

Teacher: But, there's a condition like here in Belgium. If you don't understand each other, what do you have to do? Like we do here actually? Sofia?

Sofia (Had raised her hand.): Uhm, I don't know.

Teacher: What do you have to do to, to understand French? What do you have to do? Gemma: Study.

Teacher: You will first have to learn that language.

$$
[\ldots]
$$

Jacob: But because uhm if there is just one language then uhm then it becomes a bit boring because you only hear the same language.

Teacher: Yes, that's definitely an advantage isn't it, that we have here in our class. Who wants to add something?

(Van Bruyssel 2011: 27-28 - Brussels)

Most of the students say that they believe that living in a country like Tikaland with multiple languages would be a very nice experience. The teacher confirms that a multilingual environment has many advantages and that being able to meet people that speak different languages is an enriching experience. However, there is one condition; a condition that applies to Belgium as well. To be able to communicate, you have to learn each other's language. By doing so, she emphasizes her teacher identity and underscores the importance of learning languages to the students.

Building on that conversation, students discuss the communication problems that can arise in a multilingual country. In Excerpt 14c, Emile launches the idea of introducing one official language. The teacher encourages the discussion of this idea and refers to the linguistic diversity of Belgium. She asks students to think about the possible problems resulting from having only one official language.

\section{Excerpt 14c}

Emile: Because uhm if there is someone in my spot, for example it is French, (makes gestures) "Pardon euh, tu peux un peu bouger?" Instead of uhm, trying to speak his 
own language or uhm the body language, just official language and uhm other than that all languages are allowed.

Teacher: So if, everyone, according to you everyone must learn one language?

Emile: Yes.

Teacher: And what would you choose then? Which language would you choose then? Is that possible?

Emile: Français.

Teacher: You would choose French but do you think that those who speak Dutch here in our country, that they would agree to that?

Students: No.

Teacher: And the other way around as well hu. If the Dutch speakers say "ok uhm there needs to be an official language, that's much easier, and we're going to choose Dutch". Would the French speakers agree to that?

(Van Bruyssel 2011: 27 - Brussels)

The teacher then focuses on the use of mother tongues. In Excerpt 14d, she asks the students what language they use if they are emotional.

\section{Excerpt 14d}

Teacher: Danish. Which language is it you think, the language you use when your emotions take control, Gil?

Gil: The mother tongue.

Teacher: Your mother tongue. Ok, that's a very very important language. Cause imagine, from now on, the entire world has to speak English. Now think of what we just discussed, of your, the language of your heart. Would you Gil, tomorrow, you experience something super unfair [...] and you have to tell someone otherwise you go crazy. And you have to do that in English.

Gil: Uhm.

Teacher: Would that work?

Gil (and other students): No.

Jef: Uhm Miss, it's also uhm, uhm it's not very good but I know dirty words in English. (Students laugh.) 
Teacher: Yes, would you be able to, would you be able to explain the situation very clearly and say why you feel you are treated so unfairly? Would you be able to explain that very clearly? No hu, I don't think so. So what do you think about the idea [...] to say tomorrow "ok, all languages that exist, whup, swept away, from now on we all speak English"?

Students: Miss Miss.

Teacher: Would that be a good idea?

Students: No.

Teacher: No hu. People like their language hu.

(Van Bruyssel 2011: 27 - Brussels)

The teacher emphasizes the importance of the mother tongue (for reasons of identity and because of its emotional value) and discusses how being able to express oneself in one's mother tongue might be quite different from using a foreign language to explain what exactly is going on, and how being able to make oneself understood connects with being treated fairly. Besides, as she points out: people love their language. In this short discussion, the teacher points her students to some very relevant insights and issues with respect to language (e.g., the status of English as a world language).

Finally, the teacher concludes by asking the students about their experiences in performing the task in their home languages. Most students say that this was easy and that they liked it. The teacher adds that it can be tiring to always have to speak another language than your mother tongue. By doing so, she indicates that she understands that some of the students sometimes use French at school, even if this is prohibited by the school language policy.

The above class discussion is an illustration of the potential that a multilingual task like Radio Tika has in getting students and teachers engaged in talking about their experiences with languages and reflecting on the role languages play in everyday life, at school, and in society. The task facilitates reflection on the pros and cons of having a Dutchonly policy at school or one official language in a country, and on being able to speak the home language in class. The task encourages students to compare languages and language scripts. The students' performances and experiences could easily be used as a starting point for an in-depth discussion of the role languages play in people's lives, but unfortunately, most teachers did not engage in a real reflective activity. Most teachers used the class discussion to provide the students with positive reinforcement of how great they did and how great it was hearing them speak so many languages. The teacher in Ghent in Van Bruyssel's study 
emphasized to the whole class what a wonderful job Amal did in presenting his news bulletin in English and that it was great to hear him conclude his item with a few words of Berber. By doing so, she really expressed her appreciation for the difficult language choice process Amal went through during the group work and underlined Amal's language proficiency to the other group members. Through her actions, the teacher underscores the importance of one's home language and one's proficiency in that home language. Alternatively, the third teacher in Van Bruyssel's study just emphasized that it was nice being able to hear the different languages in the classroom but that using all these languages in a real radio broadcast would be rather problematic because you would not be able to understand everything. And although we should not underestimate the importance of reflective classroom discussion to consolidate the positive impact of spontaneous LA practices (e.g., feelings of pride and competency) and embed them in a more comprehensive and situated view on language and language use, we have observed that in student-student and student-teacher interactions a lot of worthwhile spontaneous LA practices and reflections emerged as well.

\section{Conclusion}

In this chapter, we started out by outlining how the Flemish educational system is dominated by a monolingual ideology and how multilingualism (especially involving home languages that are less appreciated than more prestigious languages like English) is often seen as a hindrance rather than a resource for education. We used a multilingual task that invited students to use their whole language repertoire in making a multilingual news broadcast for the fictitious country Tikaland, as a research instrument to elicit students' and teachers' views and practices regarding multilingualism. By recording the group work, the language choices of the students, and the interactions between students and students and teachers, we were able to capture varied spontaneous LA practices. We believe this to be our major finding: numerous LA "moments" emerge if students are provided with an opportunity to use their full language repertoires in the classroom. The LA moments that we observed were very similar across the various, geographically spread out classrooms that differed considerably in students' home languages and socio-economic backgrounds. Whatever the language or socio-economic background of the students, they all marvelled over the same language aspects or struggled with the same language use issues.

Another finding was that many students were surprised to find out what their peers' home languages were. In addition, teachers did not always know what the home language of their students was or were not always aware that students spoke more than one language at home. Often teachers have an all or nothing belief about home language use: students speak either Dutch or another language (see Van Gorp and Moons 2014). The fact that students might use different languages with different family members, and the fact that their students 
have multilingual identities and a complex language repertoire is something teachers are not always aware of (Van Avermaet et al. 2016).

Finding out what languages their peers spoke, raised the students' curiosity. They started comparing languages and language scripts, and although this comparison was sometimes rather superficial or led to the wrong conclusions, the fact that they developed attentiveness for other languages can be considered positive. Besides, some of the interactions went further than scratching the surface of a language. Students started talking about the different languages that were spoken in their country of origin and about the differences between language varieties. We observed that the teacher has an important role to play in elevating these language experiences to a higher level. Through group discussions and reflective activity incidental and isolated LA moments can be linked to a deeper understanding of languages and language practices. However, these reflections were initiated rather scarcely.

We also observed some missed opportunities, although we must admit that it is not always easy for a teacher to seize the moment and develop spontaneous LA practices or short conversations of students into a group or class discussion. For example, the dialogue between Amine and Ines (Excerpt 7) contained the seeds for a very interesting class discussion about the status of different language varieties. To develop a fruitful discussion, the teacher needs to have a minimum of sociolinguistic insight and knowledge to frame and explain the specific language beliefs the students bring to the discussion. It also requires teachers to navigate students' translanguaging practices and add nuance to students' stereotyped beliefs about language (like the belief that they might be less proficient users of their home language because they are not able to write in their home language or do not know all the words to talk about a specific topic). Rather than underscoring what students cannot yet do in their home languages, teachers could encourage students to fully use their language repertoire and accommodate the limitations they perceive or experience in whatever way they seem fit. This points to one of the challenges (language) education faces: providing teachers with the professional tools to help them facilitate spontaneous LA practices and guide their students' experiences and reflections to a higher level of understanding of how language practices work (see Chapter 8 in this volume).

The multilingual task allowed students to showcase their home language or their proficiency in a foreign language. However, because of the academic language the task type elicited, students were also confronted with their own limitations in language proficiency. They often started out self-confident and ambitious, but sometimes went on to discover that they lacked the vocabulary to talk about a selected news item. In most classrooms, the teacher asked the students to prepare their radio broadcast by writing their news bulletin. However, not all languages have a written script or written tradition. Furthermore, not all 
students have developed advanced literacy skills in their home language and as a result felt frustrated by having to write the message. Teachers who want students to write down news items in their home language could provide support by allowing them to access Google Translate or having them ask their parents, siblings or other members of the community for help revising their texts at home. A benefit of this last strategy would be that it would involve parents and provide them with a sense of pride that they were able to help their children with their academic work. Most teachers were not aware of this problem beforehand. So at least, Radio Tika raised their awareness of what students can and cannot do with language, and made them realize that students have "truncated competencies" (Blommaert 2010). However, it was never the intention of the task designers to leave students with a heightened awareness of what they cannot do with their home language. Therefore, a more informal task might have suited the needs of these students better and might have helped them better to display their language proficiency. On the other hand, the Radio Tika task enabled students to find out that different parts of their language repertoire do complement and strengthen each other, through the practice of translanguaging.

We observed that it was often the teacher who encouraged students to disregard the vocabulary gaps in their home language and to use Dutch words instead. By encouraging translanguaging, the teacher endorsed a linguistic practice that is common for most multilingual students (Jordens, Van den Branden, and Van Gorp 2016; Rosiers et al. 2016) and gave a clear message that keeping the communication going was as important as - or even more important than - knowing the exact word. Allowing for translanguaging also helped to cross the divide between school and home contexts and to break through the strict compartmentalization of languages (Cornips 2012).

We detected that Radio Tika led to some contested language choices. Students had various reasons for not wanting to use their home languages: limited proficiency, experiencing feelings of shame, or having compartmentalized their different languages in languages that belong inside and outside the school. Often this led to conflicts with their peers who really wanted to hear these languages. Sometimes the teacher added to the conflicted language choice, on other occasions the teacher was able to navigate these choices and to provide the students with enough confidence to use their home language, even if, like in the case of Amal, it was only a few words in Berber at the end of their news bulletin. The fact that a multilingual task is not just interpreted as a task in which "official", national languages can be used, but also as a task in which dialects, regiolects, sociolects or, in fact, the whole range of language varieties can be used, is important to reduce the possibility of contested language choices. Furthermore, by lifting the restriction that all students need to use a different language or language variety, the teacher can defuse conflicted language choices. Moreover, by telling the students that they need not be 
proficient users of the language variety of their choice, teachers might stimulate students to take risks and encourage them to compose a news broadcast using all their available linguistic resources.

Looking at our findings, we believe they corroborate as well as add to the definition of LA proposed by Frijns et al. (Chapter 2 in this volume). First, multilingual tasks were found to be an excellent tool to bring about spontaneous LA practices as described in Frijns et al. Second, the definition proposed by Frijns et al. focuses on effects at the student level, seeing there was insufficient research on effects at the teacher level to include these in the proposed evidence-based definition of LA. Our study adds to that small body of LA research into impact on teachers. We found that multilingual tasks also allowed for LA moments in teachers. They helped teachers discover what languages their students spoke at home and provided them with insight in students' attitudes towards these and other languages. These aha experiences might help teachers more effectively tap into and design personal, bottomup LA moments for their students. They might provide teachers with a deeper understanding of their students' personal and home contexts, which, in turn, should help teachers design more effective language learning environments for their students.

Third, this study confronts us with the reality that a multilingual task or LA activities might cause some students to feel uncertain about their home language proficiency. They might experience anxiety to use their home language in the classroom and, in some cases, even outright shame. Teachers should be aware of these possible negative consequences before engaging in such tasks. If these negative feelings arise during or after the task, teachers should have the sensitivity and competencies to deal with them. They should be able to channel the negative feelings and turn them around in a positive experience. We saw how Amal's teacher succeeded in doing so. This warning extends to an approach such as Functional Multilingual Learning (Sierens and Van Avermaet 2010, 2014). The Radio Tika studies clearly show how both approaches are entwined. Opening up a space for FML allows spontaneous LA practices to occur and reflecting on these moments has the potential to advance FML, for example by underscoring the support translanguaging might offer in defining new concepts. Instead of perceiving LA and FML as two distinct approaches, both approaches could be reformulated to include one another and provide a more inclusive or integrated perspective on language and language practices. This might help to bridge the divide between language proficiency, knowledge and attitudes, or between the performance, cognitive, affective, social, and power domains (James and Garrett 1992; Frijns et al. in this volume).

Finally, we believe a multilingual task that allows for spontaneous LA practices only reaches its full potential if these incidental moments lead to at least some reflective action that helps students to connect their experiences to the reality inside and outside the school 
and to society at large. Voicing, discussing, reflecting on some of the experiences and findings of the students during the preparation and actual presentation phase in a class discussion might deepen these experiences and provide both students and teachers with an opportunity to express and discuss their beliefs, attitudes, and actions toward different languages. Linking classroom experiences with the sociolinguistic reality of language use inside and outside the school might turn out to be an enriching experience that helps empower students to counter an often negative discourse on home language use in school and in society. Such LA moments (incidental and intentional) might play a role in striving towards equity in education and might empower multilingual students or students from a lower socioeconomic background. However, we must admit that this kind of critical and empowering discourse was only minimally observed in our data.

Overall, we believe teachers and students can benefit from the introduction of several multilingual tasks over time. Encountering such tasks regularly might drive students and teachers to reflect more deeply on issues of language use and how these are connected to issues of power, identity, and equity. It might push teachers to think more on how these experiences connect to everyday sociolinguistic reality and language ideology practices. We acknowledge that teachers might need help to explore those links and that professional development opportunities should be geared to that purpose. Whatever the untapped potential of these tasks though, we believe Radio Tika provided a unique opportunity for students to give a voice to their home languages in the classroom and to be heard in a way that regular classrooms activities, especially in educational systems pervaded by a monolingual ideology, do not allow. It created an opportunity for students to voice their multilingual identity in a very positive way and for teachers to be impressed by the richness and complexity of the multilingual identities of the students in their classroom.

\section{Acknowledgements}

This chapter would not have been possible without the work and dedication of Elise Van Bruyssel, Wiene Pauwels, and Nel Heylen. Without their enthusiasm to go into Flemish classrooms and discover what the introduction of a multilingual task would reveal about students' and teachers' beliefs and practices regarding multilingualism, their careful analysis of the interview and interactional data, and our in-depth discussions about their findings, this chapter would not have been possible.

\section{Notes}

${ }^{1}$ This paragraph is based on Van Gorp and Moons (2014).

${ }^{2}$ Interestingly, in contrast to the policy documents discussed in Chapter 2 in this volume, the role of LA is not discussed anymore in any of the more recent policy documents (e.g., Crevits 
2016). For a discussion about language initiation versus LA in Flemish educational policy, see Chapter 2.

${ }^{3}$ The European school students were in the first grade of secondary education. In European schools students enter secondary education after five grades of primary education, which means that the students in the first grade of secondary education are the same age and have the same amount of school experience as students in the sixth grade of a regular primary school.

${ }^{4}$ The names of the students and teachers in the excerpts below are pseudonyms.

${ }^{5}$ The original Dutch transcripts can be obtained upon simple request.

\section{References}

Ağirdag, Orhan. 2009. All languages welcomed here. Educational Leadership 66(7). 20-25.

Ağirdag, Orhan, Kathelijne Jordens \& Mieke Van Houtte. 2014. Speaking Turkish in Belgian schools: Teacher beliefs versus effective consequences. Bilig - Journal of Social Sciences of the Turkish World 70. 7-28.

Benjamin, Rebecca. 1996. The functions of Spanish in the school lives of Mexicano bilingual children. Bilingual Research Journal 20(1). 135-164.

Berben, Martien, Kris Van den Branden \& Koen Van Gorp. 2007. We'll see what happens: Tasks on paper and tasks in a multilingual classroom. In Kris Van den Branden, Koen Van Gorp \& Machteld Verhelst (eds), Tasks in action: Task-based language education from a classroom-based perspective, 32-67. Cambridge: Cambridge Scholars Publishing.

Blommaert, Jan. 2010. The sociolinguistics of globalization. Cambridge: Cambridge University Press.

Blommaert, Jan. 2011. The long language-ideological debate in Belgium. Journal of Multicultural Discourses 6(3). 241-256.

Blommaert, Jan \& Jef Verschueren. 1998. Debating diversity: Analyzing the discourse of tolerance. London: Routledge.

Chow, Patricia \& Jim Cummins. 2003. Valuing multilingual and multicultural approaches to learning. In Sandra R. Schecter \& Jim Cummins (eds.), Multilingual education in practice: Using diversity as a resource, 32-61. Portsmouth: Heinemann.

Cornips, Leonie. 2012. Eigen en vreemd: Meertaligheid in Nederland [Native and foreign: Multilingualism in the Netherlands]. Amsterdam: Amsterdam University Press.

Crevits, Hilde. 2016. Nota van de Vlaamse Regering 797 (2015-2016) Nr. 1, ingediend op 31 mei door viceminister-president Hilde Crevits over de modernisering van het secundair onderwijs: maatregelen basisonderwijs en eerste graad [Note from the Flemish Government 797 (2015-2016) No. 1, submitted May 31st by Deputy Prime Minister Hilde 
Crevits about the modernization of secondary education: Primary school and first grade measures]. Brussels: Vlaams Parlement.

https://docs.vlaamsparlement.be/docs/stukken/2015-2016/g797-1.pdf (accessed October 20, 2016).

Cummins, Jim. 2001. Bilingual children's mother tongue: Why it is important for education? Sprogforum 19. 15-20.

Departement Onderwijs. 1998. Ontwikkelingsdoelen en eindtermen: Informatiemap voor de onderwijspraktijk: Gewoon basisonderwijs [Development goals and attainment targets: Information folder educational practices: Regular primary education]. Brussels: Afdeling Informatie en Documentatie.

Donmall, Gillian. 1985. Language awareness (NCLE Papers and Reports 6). London: Centre for Information on Language Teaching and Research.

Eldridge, John. 1996. Code-switching in a Turkish secondary school. ELT Journal 50(4)1 303-311.

Gándara, Patricia \& Megan Hopkins. 2010. Forbidden languages. English learners and restrictive language policies. New York: Teachers College Press.

García, Ofelia. 2009. Bilingual education in the 21st century: A global perspective. Chichester: Wiley-Blackwell.

García, Ofelia \& Claire E. Sylvan. 2011. Pedagogies and practices in multilingual classrooms: Singularities in pluralities. The Modern Language Journal 95(3). 385-400.

García, Ofelia \& Li Wei. 2014. Translanguaging: Language, bilingualism and education. New York: Palgrave Macmillan.

García, Ofelia, Kate Seltzer \& Daria Witt. In press. Disrupting linguistic inequalities in US urban classrooms: The role of translanguaging. In Piet Van Avermaet, Stef Slembrouck, Koen Van Gorp, Sven Sierens \& Katrijn Maryns (eds.), The multilingual edge of education. Basingstoke: Palgrave.

Hélot, Christine \& Andrea Young. 2003. Éducation à la diversité linguistique et culturelle: Le rôle des parents dans un projet d'éveil aux langues en cycle 2. [Numéro spécial de la revue LIDIL (Linguistique et Didactique des Langues)]. In Diana-Lee Simon \& Cécile Sabatier (eds.), Le plurilinguisme en construction dans le système éducatif: Contextes, dispositifs, acteurs en situation formelle d'apprentissage, 187-200.

Heylen, Nel. 2015. 30\% anderstalig, 100\% meertalig: Een kwalitatief verkennend onderzoek naar het taalkeuzeproces tijdens een meertalige taak en de impact van deze taak op leerlingen in meertalige klassen [30\% foreign languages, 100\% multilingual: A qualitative exploratory study into the language choice process during a multilingual task and the task's impact on pupils in multilingual classrooms]. Leuven: KU Leuven, Faculty of Psychology and Educational Science MA thesis. 
James, Carl \& Peter Garrett (eds.). 1992. Language awareness in the classroom. Harlow: Longman.

Jaspers, Jürgen. 2004. Tegenwerken, belachelijk doen: Talige sabotage van Marokkaanse jongens op een Antwerpse middelbare school: Een sociolinguïstische etnografie [Opposing and "doing ridiculous": Linguistic sabotage of Moroccan boys at an Antwerp secondary school: A sociolinguistic ethnography]. Antwerp: University of Antwerp doctoral dissertation.

Jaspers, Jürgen. 2011. Talking like a 'zerolingual': Ambiguous linguistic caricatures at an urban secondary school. Journal of Pragmatics 43. 1264-1278.

Jordens, Kathelijne. 2016. Turkish is not for learning, miss: Valorizing linguistic diversity in primary education. Leuven: KU Leuven doctoral dissertation.

Jordens, Kathelijne, Kris Van den Branden \& Koen Van Gorp. 2016. Multilingual islands in a monolingual sea: Language choice patterns during group work. International Journal of Bilingual Education and Bilingualism. Advance online publication. http://dx.doi.org/10.1080/13670050.2016.1220488 (accessed 9 December 2016).

Kroon, Sjaak \& Jan Sturm. 1996. Davut, Canan en de schildpad: over (taal)onderwijs in een meertalige klas [Davut, Canan and the turtle: On (language) education in the multilingual classroom]. Spiegel 14(1). 27-53.

Møller, Janus Spindler, J. Normann Jørgensen, \& Anne Holmen. 2012. Polylingual development among Turkish speakers in a Danish primary school: A critical view on the fourth grade slump. International Journal of Bilingual Education and Bilingualism 17(1). 32-54.

Moodley, Visvaganthie. 2007. Codeswitching in the multilingual English first language classroom. International Journal of Bilingual Education and Bilingualism 10(6). 707-722.

Pauwels, Wiene. 2013. Thuistaal toelaten in de klas? Een kwalitatief verkennend onderzoek naar de ervaring van leerlingen met de meertalige Radio Tika-taak [Allowing home languages at school? A qualitative exploratory study into the experiences of pupils with the multilingual Radio Tika task]. Leuven: KU Leuven, Faculty of Psychology and Educational Science MA thesis.

Pulinx, Reinhilde, Piet Van Avermaet \& Orhan Ağirdag. 2015. Silencing linguistic diversity: The extent, the determinants and consequences of the monolingual beliefs of Flemish teachers. International Journal of Bilingual Education and Bilingualism. Advance online publication. http://dx.doi.org/10.1080/13670050.2015.1102860 (accessed 16 December 2016).

Reyes, Iliana. 2004. Functions of code switching in schoolchildren's conversations. Bilingual Research Journal 28(1). 77-98.

Ramaut, Griet, Sven Sierens, Katrien Bultynck, Piet Van Avermaet, Stef Slembrouck, Koen 
Van Gorp \& Machteld Verhelst. 2013. Evaluatieonderzoek van het project 'Thuistaal in onderwijs' (2009-2012) Eindrapport: Een onderzoek in opdracht van het departement onderwijs en opvoeding van de Stad Gent [Evaluation research into the 'Home languages in Education' project (2009-2012): A research commissioned by the department of education of the City of Ghent]. Ghent \& Leuven: Ghent University \& KU Leuven.

Rosiers, Kirsten, Evita Willaert, Piet Van Avermaet \& Stef Slembrouck. 2016. Interaction for transfer: Flexible approaches to multilingualism and their pedagogical implications for classroom interaction in linguistically diverse mainstream classrooms. Language and Education 30(3). 267-280.

Sierens, Sven \& Piet Van Avermaet. 2010. Taaldiversiteit in het onderwijs: Van meertalig onderwijs naar functioneel veeltalig leren [Language diversity in education: From multilingual education to functional multilingual learning]. In Piet Van Avermaet, Kris Van den Branden \& Ludo Heylen (eds.), Goed GeGOKt? Reflecties op twintig jaar gelijkeonderwijskansenbeleid in Vlaanderen [Well bet? Reflections on twenty years policy of equal educational opportunities in Flanders], 69-87. Antwerp \& Apeldoorn: Garant.

Sierens, Sven \& Piet Van Avermaet. 2014. Language diversity in education: Evolving from multilingual education to functional multilingual education. In David Little, Constant Leung \& Piet Van Avermaet (eds.), Managing diversity in education, 204-223. Bristol: Multilingual Matters.

Steunpunt Taalwetwijzer: Het taalgebruik in het onderwijs [Support centre Language law wise: Language use in education]. http://brussel.vlaanderen.be/onderwijs.html (accessed 1 June 2013).

Strobbe, Lies. 2016. Taalbeleid of talenbeleid? De plaats van meertaligheid op school [Language policy or languages policy? The role of multilingualism at school]. In Lore Van Praag, Sven Sierens, Orhan Ağirdag, Peter Lambert, Stef Slembrouck, Piet Van Avermaet, Johan Van Braak, Piet Van de Craen, Koen Van Gorp \& Mieke Van Houtte (eds.), Haal meer uit meertaligheid: Omgaan met talige diversiteit in het basisonderwijs [Get more out of multilingualism: Dealing with linguistic diversity in elementary education], 117-130. Leuven \& The Hague: Acco.

Strobbe, Lies, Anouk Van Der Wildt, Piet Van Avermaet, Koen Van Gorp, Kris Van den Branden \& Mieke Van Houtte. 2017. How school teams perceive and handle multilingualism: The impact of a school's pupil composition. Teaching and Teacher Education 64. 93-104.

Swain, Merril, \& Sharon Lapkin. 2000. Task-based second language learning: The uses of the first language. Language Teaching Research 4(3), 251-274. 
Van Avermaet, Piet, Orhan Ağirdag, Stef Slembrouck, Esli Struys, Piet Van de Craen, Mieke Van Houtte, Fauve De Backer, Audrey De Smet, Celine Mertens, Lilith Van Biesen \& Evelien Van Hulle. 2016. MARS Meertaligheid als realiteit op school: Eindrapport [The reality of multilingualism at school: Final report]. Ghent \& Brussels: Ghent University \& Vrije Universiteit Brussel.

http://data-onderwijs.vlaanderen.be/documenten/bestand.ashx?hr=6366 (accessed 19 October 2016).

Van Bruyssel, Elise. 2011. Meertalige taken en meertalige communicatie in het Nederlandstalig basisonderwijs: Empirisch onderzoek in drie meertalige klassen in Vlaanderen en Brussel [Multilingual tasks and multilingual communication in primary education: An empirical investigation in three multilingual classes in Flanders and Brussels]. Leuven: KU Leuven, Faculty of Arts MA thesis.

Van den Branden, Kris \& Machteld Verhelst. 2008. Naar een volwaardig talenbeleid: Omgaan met meertaligheid in het Vlaams onderwijs [Towards a full-fledged language policy: Dealing with multilingualism in Flemish education]. TORB - Tijdschrift voor onderwijsrecht en onderwijsbeleid 2007-2008. 315-332.

Van Gorp, Koen. 2008. Task-based language learning in Flanders: Opportunities for second language acquisition and beyond. In Melinda Dooly \& Diana Eastment (eds.), How we're going about it? Teachers' voices on innovative approaches to teaching and learning languages, 88-102. Newcastle upon Tyne: Cambridge Scholars Publishing.

Van Gorp, Koen. 2012. Meertaligheid in Vlaanderen, een doos van Pandora? Beleidsopvattingen en stemmen uit de voorschoolse en schoolse praktijk [Multilingualism in Flanders, Pandora's box? Policy views and voices from preschool and educational practice]. In Nivja de Jong, Kasper Juffermans, Merel Keijzer \& Laurent Rasier (eds.), Papers of the Anéla 2012 Applied Linguistics Conference, 223-232. Delft: Eburon.

Van Gorp, Koen \& Nora Bogaert. 2006. Developing language tasks for primary and secondary education. In Kris Van den Branden (ed.), Task-based language education: From theory to practice, 76-105. Cambridge: Cambridge University Press.

Van Gorp, Koen \& Caroline Moons. 2014. Creating rich language environments for more than one language: A work in progress in Flemish childcare. European Journal of Applied Linguistics 2(1). 53-78.

Van Laere, Evelien, Koen Aesaert \& Johan van Braak. 2014. The role of students' home language in science achievement: A multilevel approach. International Journal of Science Education 36(16). 2772-2794.

Willemyns, Roland. 2003. Het verhaal van het Vlaams: De geschiedenis van het Nederlands in de Zuidelijke Nederlanden [The story of Flemish: The history of Dutch in the Southern Low Countries]. Antwerp: Standaard Uitgeverij. 
Young, Andrea S. 2014. Unpacking teachers' language ideologies: Attitudes, beliefs, and practiced language policies in schools in Alsace, France. Language Awareness 23(1-2). 157-171. 